\title{
Damage of Spiral Ganglion Cell Induced by Ouabain Application in Cat
}

\author{
Bo Young Kim ${ }^{1}$, Woo Yong Bae ${ }^{2}$, Jae-Ryong Kim³, and Tae Hoon Lee \\ ${ }^{\prime}$ Department of Otolaryngology-Head and Neck Surgery, Maryknoll Hospital, Busan; and \\ ${ }^{2}$ Department of Otolaryngology-Head and Neck Surgery, Dong-A University College of Medicine, Busan; and \\ ${ }^{3}$ Department of Otolaryngology-Head and Neck Surgery, Busan Paik Hospital, Inje University College of Medicine, Busan; and \\ ${ }^{4}$ Department of Otolaryngology-Head and Neck Surgery, Ulsan University Hospital, University of Ulsan College of Medicine, \\ Ulsan, Korea
}

\section{Ouabain에 의해 유도된 선택적 나선신경절 세포손상}

\author{
김보영 ${ }^{1} \cdot$ 배우용 $^{2} \cdot$ 김재룡 $^{3} \cdot$ 이태훈 ${ }^{4}$ \\ 메리놀병원 이비인후과, ${ }^{1}$ 동아대학교 의과대학 이비인후과학교실, ${ }^{2}$ 인제대학교 의과대학 부산백병원 이비인후-두경부외과학교실, \\ 울산대학교 의과대학 울산대학교병원 이비인후과학교실 ${ }^{4}$
}

\author{
Received April 1, 2014 \\ Revised May 9, 2014 \\ Accepted May 10, 2014 \\ Address for correspondence \\ Woo Yong Bae, MD \\ Department of Otolaryngology- \\ Head and Neck Surgery, \\ Dong-A University \\ College of Medicine, \\ 26 Daesingongwon-ro, Seo-gu, \\ Busan 602-715, Korea \\ Tel +82-51-240-5428 \\ Fax +82-51-253-0712 \\ E-mail doncamel@lycos.co.kr
}

Background and Objectives Auditory neuropathy is a hearing disorder characterized by the absence or the marked impairment of the auditory brainstem responses with the preservation of the cochlear microphonics (CMs) and otoacoustic emissions. This suggests that outer hair cell $(\mathrm{OHC})$ function is normal but proximal auditory function to OHCs is impaired. It is assumed that the lesion is localized at the level of the inner hair cells (IHCs), auditory nerve fibers, or the synapse between them. This study was aimed to observe the change of hearing threshold and pathology of spiral ganglion cell induced by ouabain application, and present basic data to explain the auditory neuropathy.

Materials and Method Twenty ears of twenty normal hearing cats were used in this study. Cats were treated with $100 \mu \mathrm{L}$ ouabain $(1 \mathrm{mM})$ applied on the round window. After three days, compound action potential (CAP) and CM were measured and the cochlea was obtained. Pathologic change of spiral ganglion cell was evaluated under light microscope after H\&E stain. Normal saline was injected for the control group.

Results In the ouabain group, CAP threshold was increased in all tested frequencies ( $p<$ $0.001)$ and the difference of CM threshold was not significant in all frequencies $(p>0.05)$. There was significant difference between CAP and CM threshold shift $(p<0.001)$. In the control group, there was no significant difference in CAP and CM thresholds. Light microscopic findings show that the condensed chromatin and nuclear fragments of spiral ganglion cells of an ear was exposed to ouabain, and outer hair cell and inner hair cell were not damaged.

Conclusion This study shows that the CAP threshold was significantly increased but the CM threshold was not changed in the ouabain group. Ouabain induced damage of spiral ganglion cells. This study is not sufficient to explain auditory neuropathy because threshold shift of CAP is not obvious, but it would be helpful to explain that selective damage of spiral ganglion cell would be the mechanism of auditory neuropathy.

Korean J Otorhinolaryngol-Head Neck Surg 2014;57(9):589-95

Key Words Auditory neuropathy $\cdot$ Ouabain $\cdot$ Spiral ganglion cell. 


\section{서 론}

청각신경병증(auditory neuropathy)은 소리자극에 대해 청 신경섬유에서 발생하는 활동전위의 동시성에 장애가 발생하여 유발되는 난청으로, 임상적으로는 이음향방사나 cochlear microphonic(CM)은 나타나지만 청성뇌간반응은 나타나지 않을 때 진단할 수 있다. ${ }^{1-4)}$ 병변의 위치는 내유모세포, 신경접합부, 축삭돌기, 나선 신경절 세포, 그리고 청신경섬유에 이르는 청 각전달로의 어느 한 부분 혹은 여러 부위일 수 있는데, 아직까 지 명확한 발병기전이 밝혀지지 않아 많은 동물 연구들이 이루 어지고 있다.

Ouabain은 대표적인 강심제로 세포막에 존재하는 $\mathrm{Na}, \mathrm{K}^{-}$ ATPase의 $\alpha$-subunit에 부착하여 이의 기능을 억제함으로써, 세포내 $\mathrm{Na}$ 농도를 증가시켜 이차적으로 세포내 $\mathrm{Ca}^{2+}$ 농도를 증가시킴으로써 심근을 수축시킨다. ${ }^{5,6}$ 내이와 관련된 연구는 대부분 혈관조와 와우 내 이온 항상성에 관련된 것이 주를 이루고 있는데, ${ }^{7-9)}$ ouabain이 혈관조에 많이 분포되어 있는 $\mathrm{Na}, \mathrm{K}-\mathrm{ATPase}$ 의 기능을 억제함으로써 내림프내로의 $\mathrm{Na}^{+}$이온 의 유출과 $\mathrm{K}^{+}$이온유입을 방해하여 electrical potential을 낮 춘다고 알려져 있다. ${ }^{78}$

Schmiedt 등ㄱ은 기존의 ouabain에 관련된 연구와는 다르 게 gerbil의 정원창에 ouabain을 주입하여 선택적으로 나선신 경절을 손상시킨 후 이음향방사는 정상이었으나 compound action potential(CAP) 역치는 증가되어 있음을 보고하며 이 를 청각신경병증의 동물모델 중 하나로 제시하였다. 저자는 사람과 뇌간의 구조가 유사하고, 유사한 와우 유발전위를 측 정할 수 있는 고양이의 정원창에 ouabain을 주입한 후 CAP와 $\mathrm{CM}$ 을 이용해 청력역치의 변화를 알아보고, 광학현미경을 통 한 내이의 형태학적 변화를 관찰하고자 하였다.

\section{재료 및 방법}

\section{연구 재료}

정상적인 preyer 반사를 보이는 고양이 $(1.5 \sim 2.5 \mathrm{~kg}) 20$ 마 리 20 귀를 대상으로 하였다. 15 마리 15 귀는 정원창을 통하여 ouabain을 투여하여 실험군으로 하였고, 5 마리 5 귀는 생리식 염수를 투여하고 대조군으로 하였다.

\section{수술 방법 및 전기 생리학적 검사}

$\operatorname{Ketamin}(15 \mathrm{mg} / \mathrm{kg})$ 을 근육 주사하여 고양이를 마취시킨 후 고양이의 귓바퀴 아래 후방으로 $4 \mathrm{~cm}$ 정도의 피부 절개를 가한 후 근육 아래의 bulla를 찾은 후, 전기 드릴로 소형의 구 멍을 내고 구멍을 통하여 정원창을 확인 후, 정원창 입구에 전
극을 위치시킨 후 $\mathrm{CAP}$ 와 $\mathrm{CM}$ 을 측정하였다. CAP는 Viking IVP(Nicolet, Medison, WI, USA)를 사용하였으며, 활성전극 을 두정부에, 기준전극을 검사측 귀의 정원창에, 접지전극을 반대측 이개에 부착하였다. 자극음은 $0.5 \mathrm{kHz}$ 에서 $8 \mathrm{kHz}$ 사 이의 tone pip(1 msec rise/fall, $2 \mathrm{msec}$ plateau)으로 하였고, polarity는 alternative로 하였다. 자극빈도는 $11.3 / \mathrm{sec}$, bandpass filter로 $30 \mathrm{~Hz}$ 에서 $3 \mathrm{kHz}$ 범위에 통과되었다. $\mathrm{CM}$ 은 자 극음은 $0.5 \mathrm{kHz}$ 에서 $8 \mathrm{kHz}$ 사이의 tone burst $(5 \mathrm{msec}$ rise/fall, 10 msec plateau)를 사용하였고, polarity는 rarefaction으로 하였고 나머지는 CAP와 동일한 조건으로 하였다. 청력이 정상 임이 증명된 고양이의 정원창을 통해 생리식염수로 희석한 1 $\mathrm{mM}$ 농도의 ouabain $100 \mu \mathrm{L}$ 를 투여하였고, 대조군은 동일 용 량의 생리식염수를 투여하였다. 약물 투여 후 bulla를 막고 피 부를 봉합 후, 2 세대 cephalosporine $(0.5 \mathrm{~g} / \mathrm{kg})$ 을 1 회 근육 주 사하여 실온에서 3일간 사육 후 처음과 동일한 방법으로 bulla 를 노출 시킨 후 $\mathrm{CAP}$ 와 $\mathrm{CM}$ 을 재측정하였다. 시술 중에는 온열패드를 사용하여 고양이의 체온을 일정하게 유지하였다.

\section{형태학적 관찰}

고양이들은 3일간 실온에서 사육 후 $\operatorname{ketamin}(15 \mathrm{mg} / \mathrm{kg})$ 근 육주사와 pentobarbital $(50 \mathrm{mg} / \mathrm{kg})$ 을 복막으로 주사하여 마 취시킨 이후 $\mathrm{CAP}$ 와 $\mathrm{CM}$ 을 통해 청력역치를 측정 후, 개두술 을 시행하여 측두골을 채취하였다. 채취된 와우의 정원창과 난원창을 열고, phosphate buffered $1 \%$ glutaralehyde/4\% formaldehyde에서 하루 동안 고정 후 0.1 M phosphate buffered saline로 세척하였다. 탈석회화는 dextrose로 희석시킨 $10 \%$ ethylenediamine tetraacetic acid(EDTA)에서 4주간 시행되었으며, 3일에 한번씩 새로운 EDTA 용액으로 교체하 였다.

이후 증류수로 10 분 간격으로 세 차례 세척한 후, 탈수과정 을 거쳐 와우축 중심부의 방향을 잘 알 수 있도록 위치를 정한 다음에 파라핀에 포매하였다. 각각의 와우에서 $6 \mu \mathrm{m}$ 두께의 절편들을 와우축 중심부에서 얻어 $\mathrm{H \& E}$ 염색 후 광학 현미경 으로 관찰하였다.

\section{통계분석}

실험군에서 $\mathrm{CAP}$ 와 $\mathrm{CM}$ 의 청력역치는 Wilcoxon singed rank test를 통해 통계분석 하였고, 실험군에서 $\mathrm{CAP}$ 와 $\mathrm{CM}$ 역치 증 가량의 비교와, 실험군과 대조군 간의 $\mathrm{CAP}$ 와 $\mathrm{CM}$ 역치 증가 량의 비교는 Mann-Whitney U 검정법을 사용하여 통계분석 하였다. 분석 결과는 평균표준편차로 표시하였고, 통계학적 유의성은 $p$ 값이 0.05 미만인 경우를 유의하다고 하였다. 통 계패키지는 Statistical Package for Social Science(SPSS) for 
window(version 10.0, SPSS Inc., Chicago, IL, USA)를 이용 하였다.

\section{결 과}

\section{$\mathrm{CAP}, \mathrm{CM}$ 의 변화}

Ouabain 및 생리식염수를 투여하기 전, 후 각각의 CAP와
$\mathrm{CM}$ 의 역치평균 \pm 표준편차는 Table 1 의 값과 같다. Ouabain 을 투여하기 전, 후의 CAP 역치의 변화는 모든 주파수에서 통계학적으로 의미가 있었고, $\mathrm{CM}$ 의 역치 변화는 모든 주파수 에서 통계학적 의미가 없었다(Fig. 1). 생리식염수를 투여하기 전, 후 $\mathrm{CAP}$ 와 $\mathrm{CM}$ 의 역치 변화는 모든 주파수에서 통계학적 으로 의미가 없었다(Fig. 2).

Ouabain 투여 전, 후의 CAP 역치의 증가량은 $8 \mathrm{kHz}$ 에서

Table 1. CAP and CM thresholds ( \pm standard deviation) of cats treated with ouabain or normal saline

\begin{tabular}{|c|c|c|c|c|c|}
\hline \multirow{2}{*}{ Thresholds $\pm S D(d B)$} & \multicolumn{5}{|c|}{ Frequency $(\mathrm{kHz})$} \\
\hline & 0.5 & 1 & 2 & 4 & 8 \\
\hline \multicolumn{6}{|l|}{ Ouabain } \\
\hline Pre-CAP & $47.3 \pm 8.83$ & $32.6 \pm 8.84$ & $14 \pm 7.37$ & $9.33 \pm 5.94$ & 0 \\
\hline Post-CAP & $78 \pm 5.07$ & $72.6 \pm 13.9$ & $60 \pm 17.7$ & $52 \pm 16.6$ & $42 \pm 8.62$ \\
\hline Pre-CM & $44 \pm 11.2$ & $29.3 \pm 12.8$ & $15.3 \pm 7.43$ & $12.7 \pm 4.58$ & 0 \\
\hline Post-CM & $53.3 \pm 11.7$ & $42.6 \pm 17.9$ & $23.3 \pm 11.1$ & $14.7 \pm 13.6$ & $4 \pm 5.07$ \\
\hline \multicolumn{6}{|l|}{ Normal saline } \\
\hline Pre-CAP & $44 \pm 8.94$ & $28 \pm 8.37$ & $14 \pm 8.37$ & $12 \pm 13.4$ & 0 \\
\hline Post-CAP & $38 \pm 8.37$ & $32 \pm 8.37$ & $18 \pm 13.1$ & $16 \pm 8.94$ & $2 \pm 4.47$ \\
\hline Pre-CM & $34 \pm 18.2$ & $8 \pm 8.37$ & $6 \pm 5.48$ & $2 \pm 4.47$ & $2 \pm 4.48$ \\
\hline Post-CM & $42 \pm 11.0$ & $18 \pm 4.47$ & $14 \pm 5.48$ & $8 \pm 4.47$ & $4 \pm 5.48$ \\
\hline
\end{tabular}

CAP: compound action potential, CM: cochlea microphonics
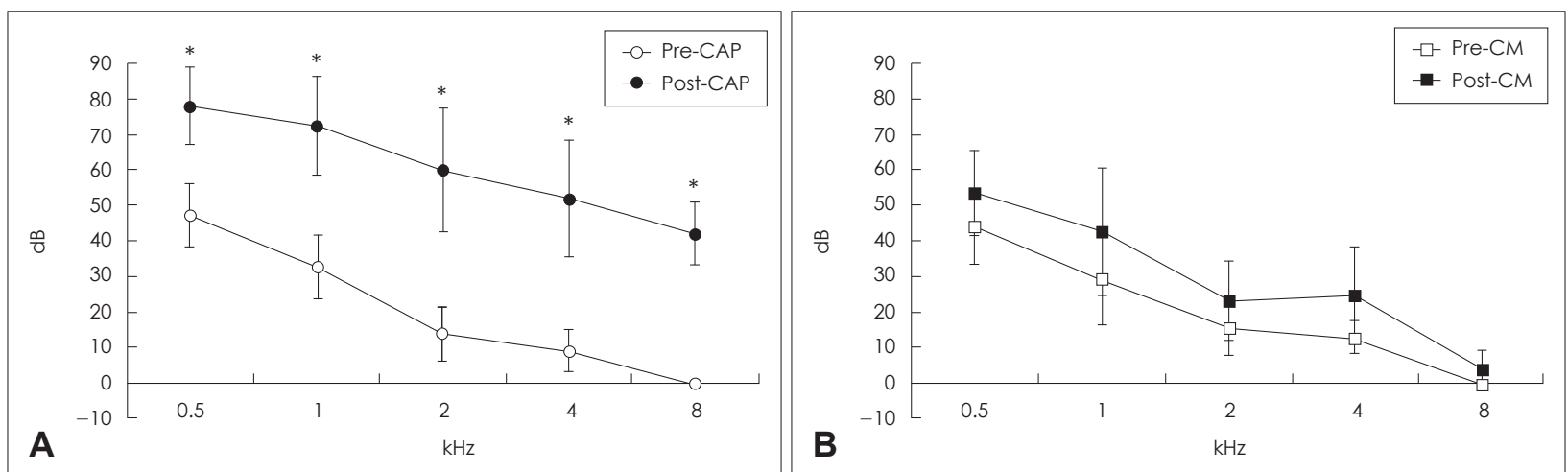

Fig. 1. CAP and $\mathrm{CM}$ thresholds of cats treated with ouabain. Open circles and squares, before treatment with ouabain. Solid circles and squares, after treatment with ouabain. CAP thresholds (A). CM thresholds (B). ${ }^{*} p<0.001$. CAP: compound action potential, CM: cochlea microphonics.
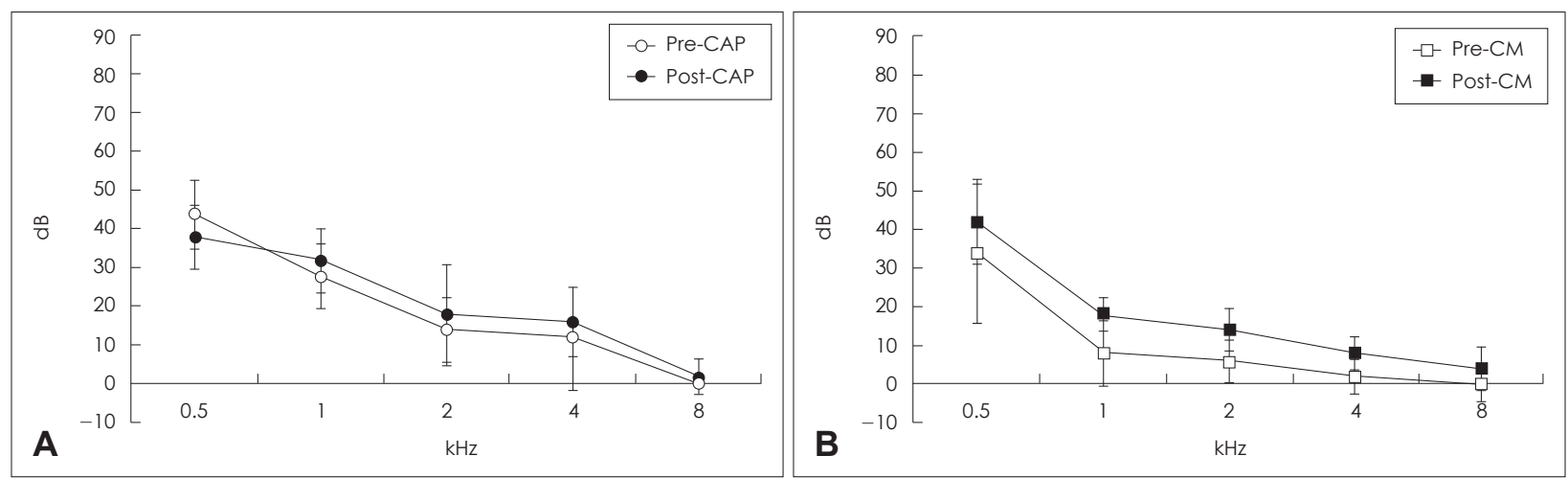

Fig. 2. CAP and CM thresholds of cats treated with normal saline. Open circles and squares, before treatment with normal saline. Solid circles and squares, after treatment with normal saline. CAP thresholds (A). CM thresholds (B). CAP: compound action potential, CM: cochlea microphonics. 
Table 2. CAP and CM threshold shifts ( \pm standard deviation) of cats treated with ouabain or normal saline

\begin{tabular}{lrrrrr}
\hline \multirow{2}{*}{ Threshold shifts \pm SD $(\mathrm{dB})$} & \multicolumn{5}{c}{ Frequency $(\mathrm{kHz})$} \\
\cline { 2 - 6 } Ouabain & \multicolumn{1}{c}{0.5} & 1 & 2 & \multicolumn{1}{c}{4} \\
$\quad$ CAP & $30 \pm 11.3$ & $40 \pm 15.1$ & $46 \pm 17.7$ & $42.7 \pm 16.7$ & $42 \pm 8.62$ \\
CM & $8.67 \pm 17.7$ & $13.3 \pm 18.8$ & $8 \pm 15.2$ & $10.7 \pm 14.4$ & $4 \pm 5.07$ \\
Normal saline & & & & \\
CAP & $-4 \pm 11.0$ & $4 \pm 5.48$ & $4 \pm 5.48$ & $4 \pm 11.0$ & $2 \pm 4.47$ \\
CM & $2 \pm 4.47$ & $8 \pm 4.47$ & $8 \pm 8.37$ & $6 \pm 5.48$ & $4 \pm 5.48$ \\
\hline
\end{tabular}

CAP: compound action potential, CM: cochlea microphonics
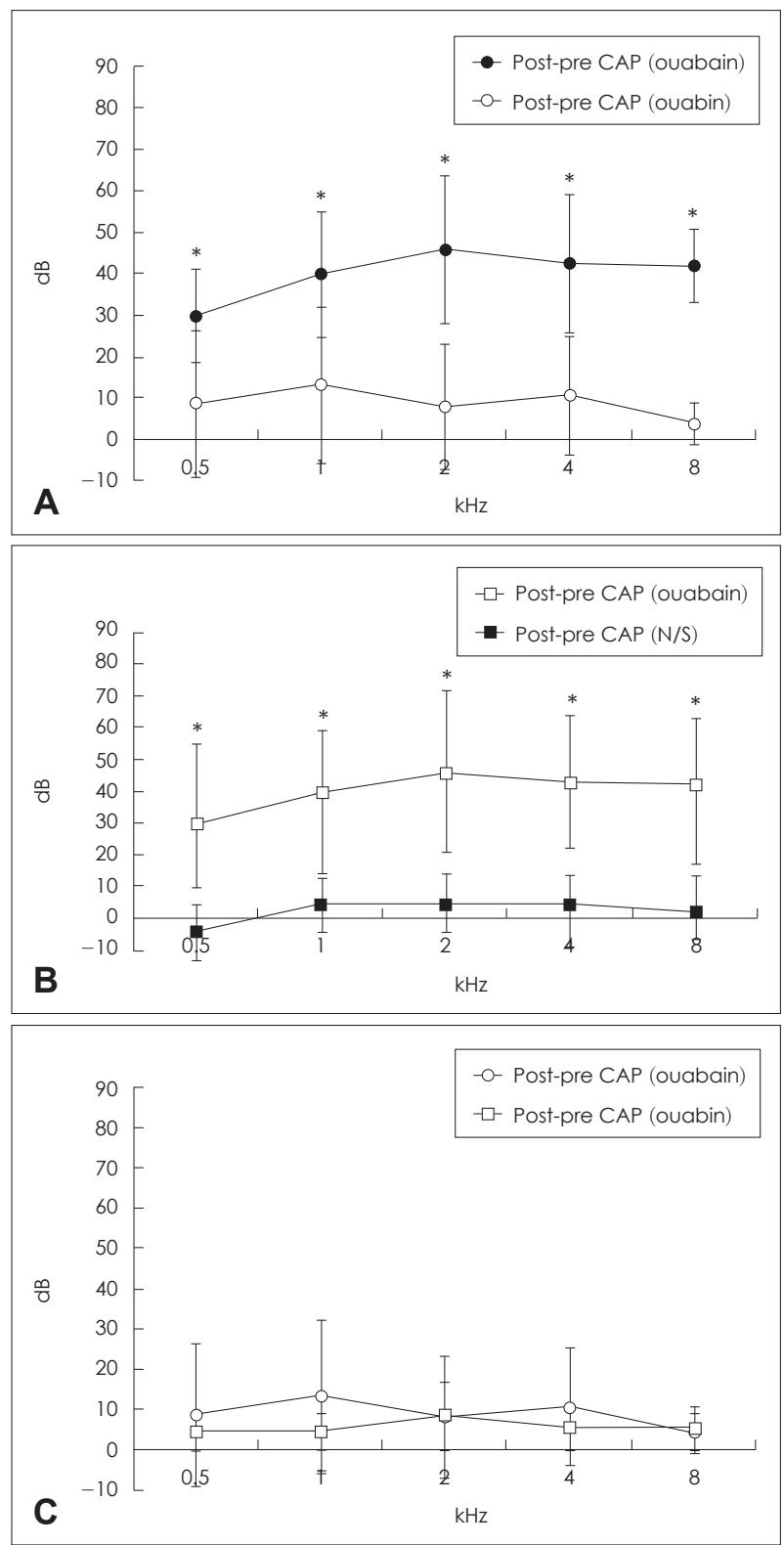

Fig. 3. CAP and CM threshold shifts of cats treated with ouabain or normal saline. CAP and CM threshold shifts of cat treated with ouabain (A). CAP threshold shifts of cats treated with ouabain or normal saline (B). CM threshold shifts of cat treated with ouabain or normal saline (C). ${ }^{*} p<0.001$. CAP: compound action potential, CM: cochlea microphonics.
$42 \pm 8.61 \mathrm{~dB}, 4 \mathrm{kHz}$ 에서 $42.67 \pm 16.7 \mathrm{~dB}, 2 \mathrm{kHz}$ 에서 $46 \pm 17.7$ $\mathrm{dB}, 1 \mathrm{kHz}$ 에서 $40 \pm 15.1 \mathrm{~dB}, 0.5 \mathrm{kHz}$ 에서 $30 \pm 11.3 \mathrm{~dB}$ 이었 고, $\mathrm{CM}$ 역치의 증가량은 $8 \mathrm{kHz}$ 에서 $4 \pm 5.07 \mathrm{~dB}, 4 \mathrm{kHz}$ 에서 $10.7 \pm 10.7 \mathrm{~dB}, 2 \mathrm{kHz}$ 에서 $8 \pm 15.2 \mathrm{~dB}, 1 \mathrm{kHz}$ 에서 $13.3 \pm 18.8$ $\mathrm{dB}, 0.5 \mathrm{kHz}$ 에서 $8.67 \pm 17.7 \mathrm{~dB}$ 이었다(Table 2).

생리식염수 투여 전, 후 $\mathrm{CAP}$ 역치의 증가량은 $8 \mathrm{kHz}$ 에서 2 $\pm 4.47 \mathrm{~dB}, 4 \mathrm{kHz}$ 에서 $4 \pm 11.4 \mathrm{~dB}, 2 \mathrm{kHz}$ 에서 $4 \pm 5.48 \mathrm{~dB}, 1$ $\mathrm{kHz}$ 에서 $4 \pm 5.48 \mathrm{~dB}, 0.5 \mathrm{kHz}$ 에서 $-4 \pm 11.4 \mathrm{~dB}$ 이었고, $\mathrm{CM}$ 역치의 증가량은 $8 \mathrm{kHz}$ 에서 $4 \pm 5.48 \mathrm{~dB}, 4 \mathrm{kHz}$ 에서 $6 \pm 5.48$ $\mathrm{dB}, 2 \mathrm{kHz}$ 에서 $8 \pm 8.37 \mathrm{~dB}, 1 \mathrm{kHz}$ 에서 $8 \pm 4.47 \mathrm{~dB}, 0.5 \mathrm{kHz}$ 에서 $2 \pm 4.48 \mathrm{~dB}$ 이었다(Table 2).

Ouabain을 투여한 실험군에서 CAP 역치 증가는 CM 역치 증가에 비해 전 주파수에서 매우 유의하게 차이가 있었다 $(p$ $<0.001$ )(Fig. 3A).

Ouabain을 투여한 실험군은 생리식염수를 투여한 대조군에 비해 전 주파수에서 $\mathrm{CAP}$ 역치 증가가 유의하였고 $(p<0.001)$ (Fig. 3B), CM 역치 증가는 전 주파수에서 유의하지 않았다 $(p>0.05)$ (Fig. 3C).

\section{형태학적 변화}

Ouabain을 투여한 실험군에서는 $\mathrm{H \& E}$ 염색상 나선신경절 세포는 핵인이 소실되고 부분적으로 핵 염색질이 응축되는 소견을 보였고, 손상된 나선신경절 세포 주변으로 백혈구 등의 염증세포는 관찰되지 않았다(Fig. 4A and C). 내유모세포 및 외유모 세포는 정상적으로 관찰되었고, 혈관조에서도 세포손 상 소견을 관찰할 수 없었다(Fig. $4 \mathrm{~A}$ and E). 생리식염수를 투 여한 대조군에서는 나선신경절, 내유모세포 및 외유모세포의 손상소견을 관찰할 수 없었다(Fig. $4 \mathrm{~B}, \mathrm{D}$ and F).

\section{고 찰}

Ouabain은 대표적인 강심제로 세포막에 존재하는 $\mathrm{Na}, \mathrm{K}-$ ATPase에 부착하여 이의 기능을 억제함으로써, 세포내의 $\mathrm{Na}$ 농도를 증가시켜 이차적으로 세포내로 $\mathrm{Ca}^{2+}$ 유입을 증가시 

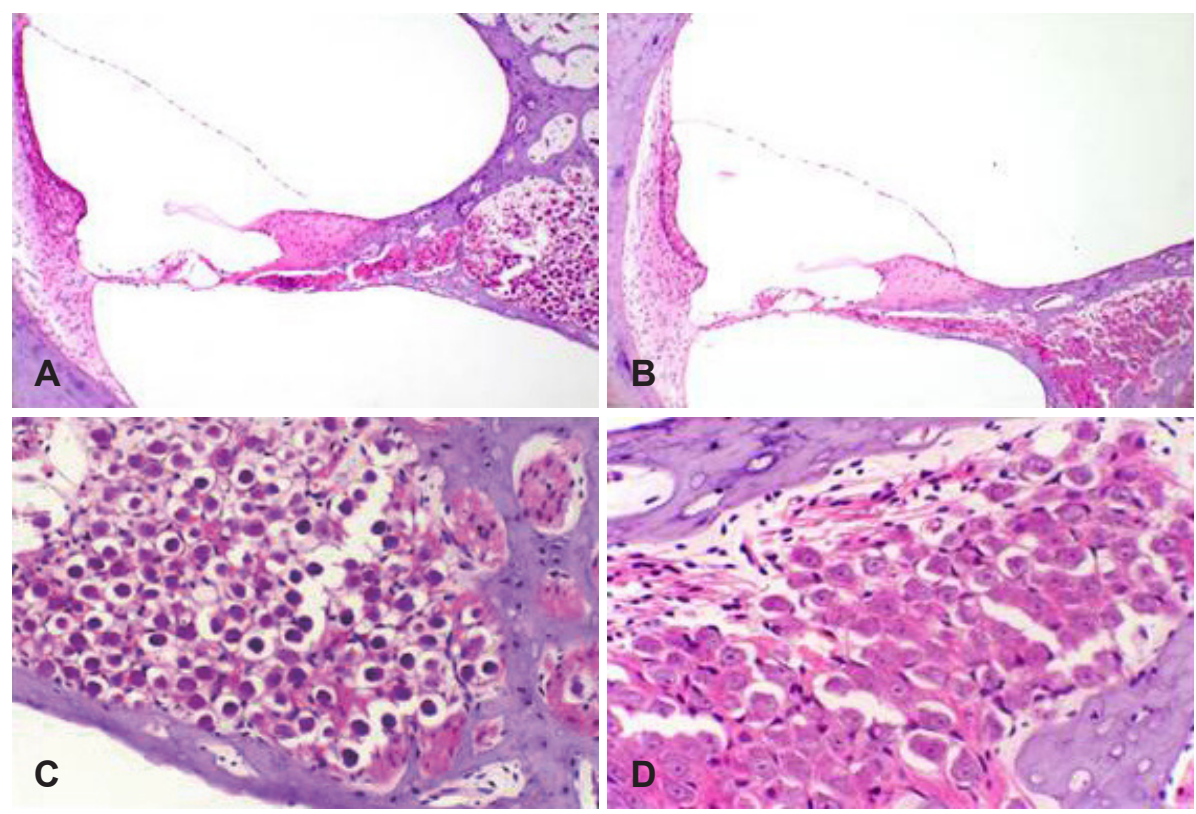

C
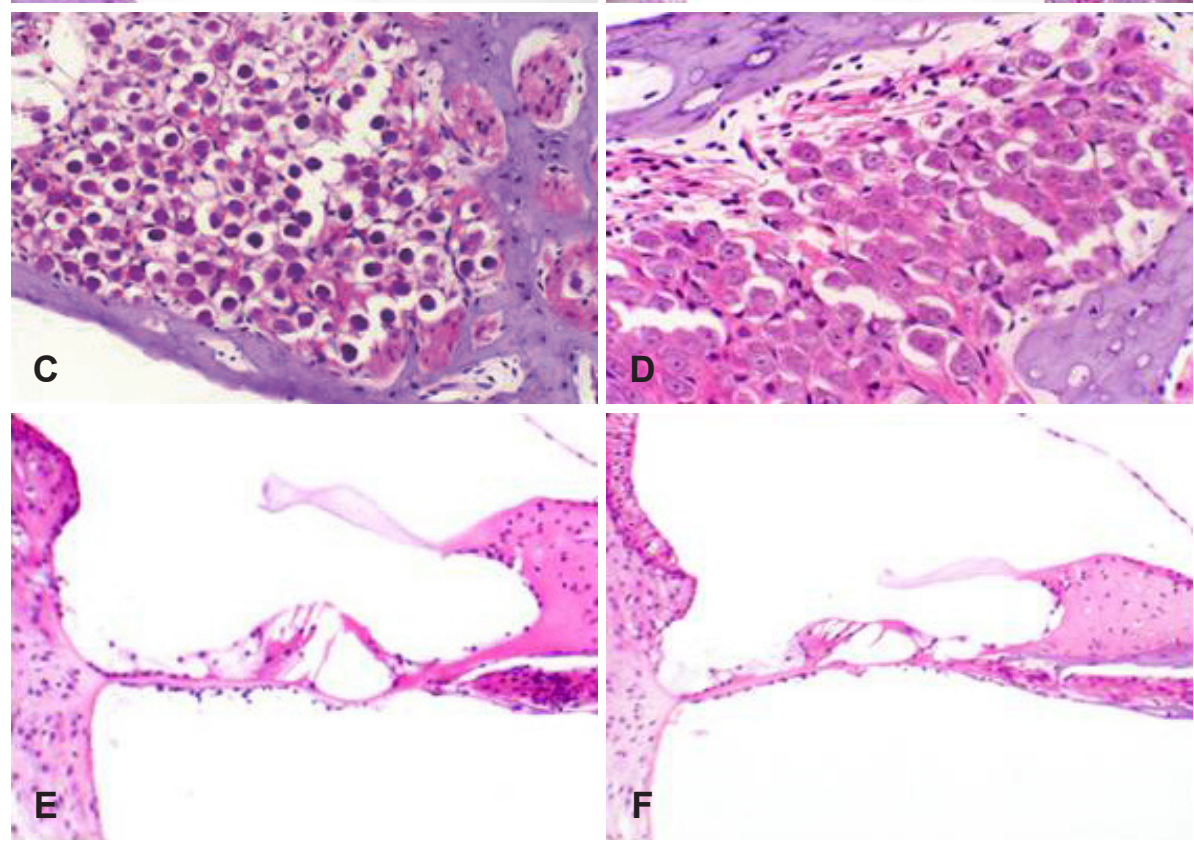

Fig. 4. Light microscopic findings. Spiral ganglion cells and organ of Corti treated with ouabain $(A)$ and normal saline $(B)(H \& E, \times 100)$. The chromatin condensation is observed in spiral ganglion cells treated with ouabain (C), but no damaged findings are observed in group treated with normal saline (D)(H\&E, $\times 200)$. Organ of Corti treated with ouabain $(E)$ and normal saline $(F)$ are not damaged $(H \& E, \times 200)$.

켜 심근을 수축시킨다.5, Ouabain을 이용한 내이에 관련된 기 존의 연구에서는 대부분 cochlear electrical potential, cochlear ion homeostasis, 혈관조의 기능을 알아보기 위하여 이용되었 다. ${ }^{7-9)}$ Konishi와 Mendelsohn" ${ }^{7}$ 은 ouabain을 기니픽의 고실계 에 관류시켰을 때 electrical potential은 감소하고, 내림프의 $\mathrm{Na}^{+}$의 농도 증가와 $\mathrm{K}^{+}$의 농도 감소를 보고하면서, ouabain이 $\mathrm{Na}, \mathrm{K}-\mathrm{ATPase}$ 의 기능을 억제하여 정상 cochlear electrical potential 생성을 방해한다고 주장하였다. Rybak과 Morizono ${ }^{8}$ 는 $\mathrm{Na}, \mathrm{K}-\mathrm{ATPa}$ e 억제제인 ouabain과 vanadate를 chinchilla 의 정원창에 주입하여 endocochlear potential이 감소함을 보 고하였다. Hamada와 Kimura'는 ouabain을 기니픽의 정원창 과 전정에 직접 주입하였을 때 유모세포와 전정계 감각세포 는 손상되나, 혈관조와 나선인대의 섬유세포는 ouabain에 덜 민감하다고 보고하였다.

Schmiedt 등은 기존의 ouabain에 관련된 연구와는 다르 게 gerbil의 정원창에 ouabain을 주입하여 선택적으로 나선신 경절을 손상시킨 동물 실험에서 이음향방사는 정상이었으나 $\mathrm{CAP}$ 역치는 증가되어 있음을 보고하였고, 이를 청각신경병증
의 동물모델로 제시하였다.

저자는 사람과 뇌간의 구조가 유사한 고양이를 실험동물로 사용하였는데, 고양이의 가청 범위는 $62.5 ~ 60000 \mathrm{~Hz}$ 로 인간 의 가청범위인 64 23000 Hz와 비교적 유사하여 다른 동물에 비해 청각유발전위를 주파수별로 측정하기가 용이하였고 사람 과 유사한 유발전위를 측정할 수 있었다. ${ }^{10)}$ 고양이의 정원창에 ouabain을 투여하였을 때, Schmiedt 등 ${ }^{5}$ 의 결과와 유사하게 $\mathrm{CAP}$ 역치는 증가하고 $\mathrm{CM}$ 역치는 변화하지 않는 청각생리학 적 검사결과를 보이면서, 광학현미경 상에서도 나선신경절의 선택적 손상을 확인할 수 있었다. 본 실험에서는 청력역치 평 가를 위하여 일반적으로 사용되는 청성뇌간반응과 이음향방 사 대신에 CAP와 $\mathrm{CM}$ 을 이용하였다. 이는 실험 과정상 ouabain을 투여하기 위해서는 정원창을 반드시 노출해야 했고, 노출된 정원창을 통한 $\mathrm{CAP}$ 와 $\mathrm{CM}$ 의 측정이 청성뇌간반응과 이음향방사의 측정보다 용이하였기 때문이다. 정원창에 위치 한 전극을 통해 측정한 CAP가 이개에서 측정한 청성뇌간반응 에 비해 근거리 측정(near-field recording)으로 소음 대 잡음 비(signal-to-noise ratio) 면에서 훨씬 더 정확한 방법이고, 청 
신경섬유의 원위부를 선택적으로 반영하는 면에서도 청성뇌 간반응의 I파보다 CAP가 더 강한 반응이므로, ouabain에 의 한 선택적 손상 대상인 나선신경절 세포를 반영하는 면에서도 청성뇌간반응보다 $\mathrm{CAP}$ 가 더 유리한 검사 방법이므로 $\mathrm{CAP}$ 를 채택하였다. ${ }^{11)}$ 외유모세포의 기능은 이음향방사와 $\mathrm{CM}$ 을 통해 평가할 수 있는데, 외유모세포의 기능이 정상이더라도 중이강 의 병변이 있거나 일정기간 보청기를 사용하면 이음향방사는 나타나지 않을 수 있으나, $\mathrm{CM}$ 은 기록될 수 있다.1,2) 실험 후 소 량의 삼출액일지라도 고양이의 bulla 내에 저류되면 외유모세 포의 기능과 상관없이 이음향방사는 나오지 않을 가능성이 있 으므로 중이의 상태와 직접적 연관이 없는 $\mathrm{CM}$ 을 검사방법으 로 사용하였다. 실제 청각신경병증의 환자에서도 이음향방사는 기록되지 않으나 $\mathrm{CM}$ 은 보존되어 있다는 여러 보고가 있다. ${ }^{12,13)}$

본 실험에서는 $0.5,1,2,4,8 \mathrm{kHz}$ 에서 $\mathrm{CAP}$ 와 $\mathrm{CM}$ 을 측정 하였는데, 고양이의 실제 가청범위는 $62.5 \sim 60000 \mathrm{~Hz}$ 로 실험 상 측정한 주파수들은 가청범위 중 중간범위의 주파수(midrange frequency)에 해당하게 된다. Ouabain을 투여하기 전 $\mathrm{CAP}$ 와 $\mathrm{CM}$ 의 역치가 고주파수로 갈수록 낮아지는 경향을 보 이는데(Table 1), 실제로 고양이는 중간범위의 주파수에서 가 장 낮은 청력역치를 보이고, 몇몇의 저자들은 $8 \mathrm{kHz}$ 에서의 청력역치가 평균 $-3 \mathrm{~dB},-17 \mathrm{~dB}$ 을 보여 가장 낮은 역치를 보인 다고 하였다. ${ }^{10,14}$ 본 실험에서도 ouabain을 투여하기 전 $8 \mathrm{kHz}$ 에서 $\mathrm{CAP}$ 와 $\mathrm{CM}$ 의 역치가 $0 \mathrm{~dB}$ 을 보였는데 이전의 결과와 유 사하다 할 수 있다(Table 1).

Ouabain을 투여한 군에서는 전 주파수에서 통계적으로 유 의하게 $\mathrm{CAP}$ 의 역치가 증가하였다(Fig. 1A). 이는 정원창을 통 해 투입된 ouabain이 적어도 고양이의 와우내 중간 주파수 영 역까지 확산되어 유사한 농도로 영향을 미쳤을 것으로 생각된 다. Ouabain을 투여한 군의 $\mathrm{CAP}$ 와 $\mathrm{CM}$ 의 청력역치 증가의 차이는 통계적으로 매우 유의하였다(Fig. 3). Ouabain을 주입 한 실험군은 생리식염수를 주입한 대조군에 비해 CAP 역치 증 가의 차이가 전 주파수에서 유의하게 존재하였고, $\mathrm{CM}$ 역치 증 가의 차이는 전 주파수에서 유의하게 존재하지 않았다(Fig. 3).

Ouabain을 투여한 군에서 CAP 역치 증가뿐만이 아니라 $\mathrm{CM}$ 의 역치도 통계학적으로 의미가 있지는 않지만 증가되는 경향을 보이는데(Fig. 1B), 이는 ouabain에 의한 내림프액의 이온조성의 변화로 인해 외유모세포에 간접적인 영향을 미쳤 기 때문으로 생각된다. 외유모세포에는 $\mathrm{Na}, \mathrm{K}-\mathrm{ATPase}$ 가 매우 적게 분포하기 때문에 ouabain에 의한 직접적인 영향보다는 혈관조의 $\mathrm{Na}, \mathrm{K}-\mathrm{ATPase}$ 에 작용한 ouabain에 의해 내림프내 $\mathrm{Na}^{+}$농도의 증가 등 이온조성 변화에 의한 이차적인 외유모 세포의 손상으로 생각된다. ${ }^{7)}$ Ouabain을 투여한 군에서 CAP 역치의 증가가 클 것으로 예상하였으나, 전 주파수에서의 30
$46.6 \mathrm{~dB}$ 정도의 역치 증가만이 있었는데, 이는 투여하는 ouabain의 용량과 농도의 영향일 것으로 생각한다. 이를 확인하 기 위하여 다양한 농도와 양의 ouabain을 이용한 추가적인 실 험이 필요할 것으로 생각된다. 하지만 투여하는 ouabain의 용 량과 농도가 증가한다면 이차적인 외유모세포의 손상 정도도 커질 것으로 생각된다.

Ouabain을 투여한 실험군에서는 $\mathrm{H} \& \mathrm{E}$ 염색상 나선신경절 세포의 핵인 소실과 핵 염색질의 응축을 관찰할 수 있었으나, 내유모세포, 외유모세포와 혈관조의 세포손상은 관찰할 수 없었다. 기존의 실험과 다르게 ouabain이 나선신경절 세포에 선택적으로 손상을 야기한 이유는 Na,K-ATPase의 ouabain 결합부위가 있는, $\alpha$-subunit의 아형의 분포와 형태 때문으로 생각된다. Na,K-ATPase는 대부분의 척추동물의 세포막에 존 재하면서, $\mathrm{Na}^{+}$와 $\mathrm{K}^{+}$를 세포 내외로 능동적 수송시켜 체내의 이온 및 체액의 항상성을 담당하는 효소로서 내이에서는 내 림프와 외림프의 이온 구성 및 항상성에 중요한 역할을 한 다. ${ }^{15,16)} \mathrm{Na}, \mathrm{K}-\mathrm{ATPase}$ 는 촉매작용을 하는 $\alpha$-subunit과 효소 의 성숙과 $\alpha$-subunit의 안정화에 작용하는 $\beta$-subunit으로 구 성되어 있는데, 각각의 여러 개의 아형이 존재하고 내이에서 다 르게 분포한다. ${ }^{1,13} \alpha_{1}$ 은 혈관조와 나선연에, $\alpha_{2}$ 는 나선인대, 나 선연, 나선신경절에, $\alpha_{3}$ 는 나선신경절과 청신경에 주로 분포하 는데, $\alpha_{1}$-subunit은 ouabain에 대한 감수성이 낮고, 나선신경 절 세포에 많이 분포하는 $\alpha_{2}$-와 $\alpha_{3}$-subunit이 ouabain에 대 한 감수성이 높은데, 그 중 주로 나선신경절과 청신경에 분포 하는 $\alpha_{3}$-subunit이 ouabain에 대한 감수성이 가장 높기 때문 에, ouabain이 나선신경절을 선택적으로 손상시켰다고 생각 한다. ${ }^{16-18)}$

이 연구는 환자에 대한 생검의 제한으로 아직까지 정확한 병 변 및 병태 생리가 밝혀져 있지 않은 청각신경병증에 관한 이 해를 돕기 위해, ouabain을 투여하여 청력역치 및 내이의 형 태학적 변화를 알아보았다. 하지만 이 연구에서 ouabain을 이 용한 선택적 나선신경절의 손상이 청각신경병증에 합당한 동 물 모델이 되기 위해서는 외유모세포의 손상을 최소로 하면 서 광범위한 나선신경절 세포 손상을 야기하는 ouabain의 적정 농도 및 용량 조사가 추가적으로 필요할 것으로 생각된 다. 그리고 ouabain을 투여 후 시간별 청력 변화 및 형태학적 변화 추이를 관찰하여 ouabain의 장기적인 효과에 대한 연구 와 나선신경절 세포 손상의 정량적 측정과 $\mathrm{CAP}$ 의 청력역치 증 가 정도와의 상관관계에 대한 추가적인 연구가 필요하다고 판 단한다.

\section{Acknowledgments}

This work was supported by the Dong-A University research fund. 


\section{REFERENCES}

1) Kim LS, Jung SW, Lee SH, Heo SD. Auditory neuropathy: a report of three cases. Korean J Otolaryngol 2003;46(10):847-81.

2) Starr A, Picton TW, Sininger Y, Hood LJ, Berlin CI. Auditory neuropathy. Brain 1996;119(Pt 3):741-53.

3) Rance G, Beer DE, Cone-Wesson B, Shepherd RK, Dowell RC, King $\mathrm{AM}$, et al. Clinical findings for a group of infants and young children with auditory neuropathy. Ear Hear 1999;20(3):238-52.

4) Harrison RV. An animal model of auditory neuropathy. Ear Hear 1998; 19(5):355-61.

5) Schmiedt RA, Okamura HO, Lang H, Schulte BA. Ouabain application to the round window of the gerbil cochlea: a model of auditory neuropathy and apoptosis. J Assoc Res Otolaryngol 2002;3(3):223-33.

6) Lingrel JB, Kuntzweiler T. Na+,K(+)-ATPase. J Biol Chem 1994; 269(31):19659-62.

7) Konishi T, Mendelsohn M. Effect of ouabain on cochlear potentials and endolymph composition in guinea pigs. Acta Otolaryngol 1970; 69(3):192-9.

8) Rybak LP, Morizono T. Effects of topical sodium potassium ATPase inhibitors upon endocochlear potential in chinchilla. Otolaryngol Head Neck Surg 1982;90(6):808-13.

9) Hamada M, Kimura RS. Morphological changes induced by administration of a $\mathrm{Na}+, \mathrm{K}+$-ATPase inhibitor in normal and hydropic inner ears of the guinea pig. Acta Otolaryngol 1999;119(7):778-86.

10) Neff WD, Hind JE. Auditory thresholds of the cat. J Acoust Soc Am
1955;27:480-3.

11) Santarelli R, Arslan E. Electrocochleography in auditory neuropathy. Hear Res 2002;170(1-2):32-47.

12) Starr A, Sininger Y, Nguyen T, Michalewski HJ, Oba S, Abdala C. Cochlear receptor (microphonic and summating potentials, otoacoustic emissions) and auditory pathway (auditory brain stem potentials) activity in auditory neuropathy. Ear Hear 2001;22(2):91-9.

13) Deltenre P, Mansbach AL, Bozet C, Christiaens F, Barthelemy P, Paulissen D, et al. Auditory neuropathy with preserved cochlear microphonics and secondary loss of otoacoustic emissions. Audiology 1999;38(4):187-95.

14) Heffner RS, Heffner HE. Hearing range of the domestic cat. Hear Res 1985;19(1):85-8.

15) Lingrel JB, Croyle ML, Woo AL, Argüello JM. Ligand binding sites of Na,K-ATPase. Acta Physiol Scand Suppl 1998;643:69-77.

16) Erichsen S, Zuo J, Curtis L, Rarey K, Hultcrantz M. Na,K-ATPase alpha- and beta-isoforms in the developing cochlea of the mouse. Hear Res 1996;100(1-2):143-9.

17) Zuo J, Curtis LM, Yao X, Ten Cate WJ, Rarey KE. Expression of Na, K-ATPase alpha and beta isoforms in the neonatal rat cochlea. Acta Otolaryngol 1995;115(4):497-503.

18) Hara Y, Nikamoto A, Kojima T, Matsumoto A, Nakao M. Expression of sodium pump activities in BALB/c 3T3 cells transfected with cDNA encoding alpha 3 -subunits of rat brain $\mathrm{Na}+, \mathrm{K}+$-ATPase. FEBS Lett 1988;238(1):27-30. 